\title{
Anaerobic Biofilm Enriched With an Ammonia Tolerant Methanogenic Consortium to Improve Wastewater Treatment in The Fishing Industry
}

Manuel Alarcon ( $\square$ manuel.alarcon@uach.cl)

Universidad Austral de Chile https://orcid.org/0000-0002-8585-2514

Nathaly Ruiz-Tagle

Universidad de Concepción: Universidad de Concepcion

Fidelina Gonzalez

Universidad de Concepcion

Paz Jopia-Contreras

Universidad de Valparaiso

Estrella Aspé

Universidad de Concepcion

Homero Urrutia

Universidad de Concepcion

Katherine Sossa

Universidad de Concepcion

\section{Research Article}

Keywords: Wastewater biological treatment, biofilm, ammonia shock, methanogenic reactor, Methanosarcinaceae. 16S rDNA

Posted Date: August 23rd, 2021

DOI: https://doi.org/10.21203/rs.3.rs-647724/v1

License: (c) (i) This work is licensed under a Creative Commons Attribution 4.0 International License. Read Full License 


\section{Abstract}

The digestion efficiency of liquid industrial wastes increases when using bioreactors colonized by microbial biofilms. High concentrations of proteins derived from the fish processing industry lead to the production of ammonia, which inhibits methane production. Two bioreactors were constructed to compare methanogenic activity: one enriched with mMPA consortia (control bioreactor), and the second with $\mathrm{NH}_{3}$ tolerant consortia (treatment bioreactor). Ammonia tolerant activity was assessed by applying an ammonia shock (755 $\mathrm{mg} \mathrm{NH}_{3} / \mathrm{L}$ ). Methane production, consumption of total organic carbon (TOC) and the taxonomic composition of bacteria and archaea was evaluated using 16S rDNA in the acclimatization, ammonia shock, and recovery phases. The ammonia shock significantly affected both methane production and the consumption of TOC in the control reactor $(p<0.05)$ and taxonomical composition of the microbial consortia (OTU). These values remained constant in the treatment reactor. The analysis of biofilm composition showed a predominance of Methanosarcinaceae (Methanomethylovorans sp., and probably two different species of Methanosarcina sp.) in bioreactors. These results demonstrate that using acclimated biofilms enriched with ammonia tolerant methanogens control the inhibitory effect of ammonia on methanogenesis.

\section{Introduction}

A common waste management practice that controls odour and organic matter pollution is anaerobic digestion (Vidal et al. 2000). It is defined as the biological conversion of organic material into a variety of by-products, during which microorganisms perform cooperative and syntrophic processes to convert complex substrate mixtures into biogas that contains mainly methane (65-70\%) and carbon dioxide (Kato \& Watanabe 2010). This process allows energy to be recovered in the form of methane, which can replace fossil fuels for in-situ heating and electricity, reducing negative environmental effects, including global warming and acid rain (Gupta et al. 2012). Another advantage is that it is a relatively inexpensive process, making it a cost-effective way to produce energy (Angelidaki et al. 2011).

Treatment efficiency depends on the taxonomical composition of the microbial consortia.

Methanogenesis is the limiting step in anaerobic processes, affected by physicochemical parameters such as high levels of $\mathrm{H}_{2} \mathrm{~S}$ and $\mathrm{NH}_{3}$ in wastewater derived from the fishing industry (Sossa et al. 2004). The treatment of liquid industrial wastes (LIW) from the fishing industry faces periods of high organic and nutrient loads, as it is a seasonal activity. During this time, high concentrations of ammonia and sulphate cause the inhibition of methane production and poor bioreactor functionality. These bioreactors are containers with specific parameters for growing microbial communities that decompose organic material input. SRM (Sulphate Reduction Microorganisms) exhibit a higher affinity for common substrates when compared to MPA (Methane Production Archaea), therefore, reactions usually favour sulphate reduction (Mohan et al. 2005).

Moreover, protein hydrolysis produces a-acetoacids which are reabsorbed as nourishment and cause ammonia discharge, which increases alkalinity. It has been reported that free ammonia $\left(\mathrm{NH}_{3}\right)$ has higher 
inhibitory effects on methanogenesis than $\mathrm{NH}_{4}{ }^{+}$(Sossa et al. 2004). $\mathrm{NH}_{3}$ concentration depends largely on the $\mathrm{pH}$ of the medium and, to a lesser degree, temperature. For example, the $\mathrm{NH}_{3}$ concentration at $\mathrm{pH} 7$ is close to $1 \%$ but increases to $10.2 \%$ at pH 8 (Kayhanian 1999). High ammonia concentration and susceptibility of methanogenic archaea to ammonia have been demonstrated in several studies (Procházka et al. 2012). Decreases in methanogenic activity have been reported due to restricted availability of acetate as a carbon source for MPA (Sung \& Liu 2003). However, microorganisms acclimated to high ammonia concentrations can sustain their growth and digestive activity in protein-rich effluents (Calli et al. 2005). Omil et al. (1995) recommend that substrates with high initial total ammonia nitrogen (TAN) and protein content (e.g., seafood processing industry) should be treated anaerobically using selected sludge containing up to $3000 \mathrm{mg} / \mathrm{L}$ of $\mathrm{NH}_{3}$ (corresponding to $150 \mathrm{mg}$ of free ammonia nitrogen (FAN)/L at pH 7.6). Strategies have been described in order to solve the problems associated with high $\mathrm{H}_{2} \mathrm{~S}$ production by enriching the microbial community with MMPA (methylaminotrofic Methane Production Archaea). Methylated amines are abundant in fishery waste and cannot be used by SRM as a substrate, but it has been reported that $\mathrm{NH}_{3}$ effects can be minimized by using mMPA tolerant to high ammonia concentrations (Sossa et al. 2004).

Given this background, the main objective of this study was to evaluate the use of biofilms enriched with a consortium of ammonia tolerant mMPA in reactors used for treatment of industrial fishery waste, in order to improve ammonia shock tolerance during the purification process of liquid discharge effluents rich in proteins and sulphates, and to characterize the main taxonomic groups composing the biofilm before, during and after ammonia shock in a bioreactor, this improvement of the biofilm within the concept of bioaugmentation of microorganisms.

\section{Materials And Methods}

\section{Isolation and growth kinetics of ammonia tolerant mMPA consortia biofilm}

Ammonia tolerant mMPA consortia (hereinafter $\left(\mathrm{NH}_{3}\right)$-mMPA) were isolated from a fishing industry methanogenic reactor exposed to increasing ammonia concentrations, following the physicochemical conditions and protocols described by Sossa et al. (2004). A final concentration of $1 \times 10^{6} \mathrm{cells} / \mathrm{mL}$ was inoculated into each vial to isolate consortia. Triplicate samples were taken every two days from the vials to determine methane concentrations in the biogas by using gas chromatography (Pham et al. 2013). Total mMPA concentration was assessed using the Most Probable Number technique, as recommended by the American Public Health Association (APHA 1992).

\section{Scanning Electron Microscopy}

To evaluate the attachment of $\left(\mathrm{NH}_{3}\right)$-mMPA consortia on ceramic, the support was washed in a $35 \mathrm{kHz}$ ultrasound bath and observed with a scanning electron microscope (SEM) (ETEC Autoscan U-1), as 
described by Anderson et al. (1951).

\section{Design of an anaerobic biofilm enriched with $\left(\mathrm{NH}_{3}\right)$-mMPA under $\mathrm{NH}_{3}-\mathrm{N}$ shock}

Two anaerobic upflow fixed bed reactors were used: Control (CR) and Treatment (TR). CR was enriched with mMPA, while TR was enriched with $\left(\mathrm{NH}_{3}\right)$-mMPA. Fixed bed reactors with retained biomass systems improve when the biofilms formed are fixed to ceramic rings, avoiding large dangerous $\mathrm{pH}$ fluctuations and liberating micronutrients to microbial communities (Urrutia et al. 1999). Total and bed volume for both $\mathrm{CR}$ and TR were $2 \mathrm{~L}$. The bioreactors were semi-continuous fed with fishing industry model effluent medium (2.45 g/L Total Organic Carbon, 48.8mg NH3-N/L, 82.3mg/L sulphate, $181 \mathrm{mg} / \mathrm{L}$ sulphide and a salinity of $13.7 \mathrm{~g} / \mathrm{L}$, at pH 7.5, Sossa et al. 2004) at organic loading rate (OLR) of $0.98 \mathrm{~g} \mathrm{DOC}$ added $/ \mathrm{L}$ reactor/d and hydraulic retention time (HRT) of $5 \mathrm{~d}$. Methylamine was used as the main carbon source. Ammonia concentration was $320-430 \mathrm{mg} / \mathrm{L}$, in all cases, ammonium chloride was added to obtain the unionized ammonia concentration ( $\mathrm{mg} \mathrm{NH} 3-\mathrm{N} / \mathrm{L}$ ). TR was inoculated with $\left(\mathrm{NH}_{3}\right)$-mMPA at a final concentration of $10^{6}$ cells $/ \mathrm{mL}$.

In the enrichment phase (phase A), bacterial activity was inhibited with piperacillin ( $0.128 \mathrm{~g} / \mathrm{L}), \mathrm{SRM}$ activity with 2-mercaptoethane sodium sulfonate (mesna, $0.16 \mathrm{mg} / \mathrm{L}$ ) and yeast activity with cycloheximide $(0.4 \mathrm{~g} / \mathrm{L})$ in both reactors. The bioreactors were kept under these conditions for 3 months, allowing biofilm settlement (phase A) and acclimatization (phase B) before carrying out further analysis. Both bioreactors were supplemented with the fishing industry model effluent without inhibitors and maintained at a concentration of $37.7-128 \mathrm{mg} \mathrm{NH}_{3}-\mathrm{N} / \mathrm{L}$ in the medium at $\mathrm{pH} 7.5$ for a hydraulic retention time of 5 days and incubated at $30^{\circ} \mathrm{C}$ for 3 months to allow anaerobic biofilm formation. After acclimatization (phase B), both bioreactors were exposed to an ammonia shock treatment $\left(755 \mathrm{mg} \mathrm{NH}_{3^{-}}\right.$ $\mathrm{N} / \mathrm{L}$ ) (phase $\mathrm{C}$ ). The methanogenic activity at different ammonia concentrations was monitored.

\section{Chemical analysis of Bioreactor performed to evaluate performance}

Total organic carbon (TOC), alkalinity, sulphate concentration, and volatile suspended solids were analysed according to standard methods (APHA 1992). Methane determination by gas chromatography consisted of the injection of $1 \mathrm{~mL}$ of biogas in a 1000 AGC Hach Carle Series chromatograph. Ammonia concentration was estimated (expressed as $\mathrm{mg} \mathrm{NH}_{3}-\mathrm{N} / \mathrm{L}$ ) according to the corrected formula (Clegg \& Whitfield 1995).

\section{Total microbial count}

Biofilm analysis was carried out according to the protocol described by Hobbie et al. (1977). Samples were taken every $48 \mathrm{~h}$ from both CR and TR. Total bacterial count was performed using the direct epifluorescence technique with a LEICA Confocal Laser Microscope, mod. TCS NT. 
amplification, cloning and sequencing of ( $\left.\mathrm{NH}_{3}\right)$-mMPA consortia 16S rDNA: Genomic DNA of $\left(\mathrm{NH}_{3}\right)^{-}$ mMPA consortia was extracted using a mini Beadbeater (Biospec Products, Bartlesville, Okla) and the FastDNA® SPIN Kit for Soil (MP Biomedicals LLC). Genomic DNA cloning was carried out by amplifying $\left(\mathrm{NH}_{3}\right.$ )-mMPA 16S rDNA, using 21F (Abdallah et al. 2016) and 9R primers (Jurgens et al. 1997). The PCR amplification mix used was: DNA template, 1 X PCR buffer (with $1.5 \mathrm{mM} \mathrm{MgCl}_{2}$, Roche), $2 \mathrm{mM}$ dNTPs, 2 $\mathrm{pM}$ of each primer and $0.04 \mathrm{U} / \mu \mathrm{l}$ pfu polymerase (Roche). The PCR program amplification cycling protocol for amplification was DNA melting at $95^{\circ} \mathrm{C}$ for $2 \mathrm{~min}$, followed by 30 cycles of $30 \mathrm{~s}$ at $95^{\circ} \mathrm{C}$, annealing at $40^{\circ} \mathrm{C}$ for $30 \mathrm{~s}$, extension at $73^{\circ} \mathrm{C}$ for $3 \mathrm{~min}$, and a final extension at $73^{\circ} \mathrm{C}$ for $5 \mathrm{~min}$. PCR products were loaded in an agarose gel $(1.5 \%)$, isolated and purified using the MiniElute gel purification kit (Qiagen), concentrated and quantified. Amplified fragments of purified rDNA were cloned using the Zero Blunt Cloning kit (Invitrogen). Amplified fragments obtained in the PCR reaction with M13F/M13R primers were cleaned using PCR clean-up kit plates and sequenced using ABI PRISM Big Dye Terminator v3.1 Cycle Sequencing kit, using an AB3100 Genetic Analyser from Applied Biosystems (Hitachi).

\section{PCR-DGGE Community comparison (gel Electrophoresis with denaturing gradient)}

Biofilms obtained from the bioreactor were suspended and concentrated by centrifugation at $9.300 \mathrm{~g} \times 5$ min for DNA isolation using the FastDNA® SPIN Kit for Soil (MP Biomedicals LLC). 16S rRNA gene was amplified using the primers described in the following section. A nested PCR was performed to obtain 16S rRNA gene fragments (Visser et al. 2009). The primers used for archaea were 21F/915R (PCR 1) and 344F-GC/915R (Abdallah et al. 2016) (PCR 2). A PCR program for archaeal DNA amplification was DNA melting at $95^{\circ} \mathrm{C}$ for $2 \mathrm{~min}$, followed by 10 cycles of $30 \mathrm{~s}$ at $95^{\circ} \mathrm{C}$, annealing at $71^{\circ} \mathrm{C}$ for $45 \mathrm{~s}$ (decreasing $1^{\circ} \mathrm{C} /$ cycle), extension at $72^{\circ} \mathrm{C}$ for $1 \mathrm{~min}$, followed by 20 cycles of $30 \mathrm{~s}$ at $95^{\circ} \mathrm{C}$, annealing at $61^{\circ} \mathrm{C}$ for $45 \mathrm{~s}$, extension at $72^{\circ} \mathrm{C}$ for $1 \mathrm{~min}$, and finally the extension at $72^{\circ} \mathrm{C}$ for $10 \mathrm{~min}$. The primers used for bacteria were 341F/907R (Beck et al. 2013) (PCR 1) and 341F-GC/534R (PCR 2) (Dar et al. 2005). The PCR reaction mix contained DNA template 1X PCR buffer (with $1.5 \mathrm{mM} \mathrm{MgCl}_{2}$, Promega), $0.2 \mathrm{mM}$ dNTPs, 0.5 $\mu \mathrm{M}$ of each primer and $0.025 \mathrm{U} / \mu \mathrm{L}$ Gotaq polymerase. A PCR program for bacterial DNA amplification was DNA melting at $95^{\circ} \mathrm{C}$ for $2 \mathrm{~min}$, followed by 20 cycles of $30 \mathrm{~s}$ at $95^{\circ} \mathrm{C}$, annealing at $65^{\circ} \mathrm{C}$ for $45 \mathrm{~s}$ (decreasing $0.5^{\circ} \mathrm{C} / \mathrm{cycle}$ ), extension at $72^{\circ} \mathrm{C}$ for $1 \mathrm{~min}$, followed by 10 cycles of $30 \mathrm{~s}$ at $95^{\circ} \mathrm{C}$, annealing at $55^{\circ} \mathrm{C}$ for $45 \mathrm{~s}$, extension at $72^{\circ} \mathrm{C}$ for $1 \mathrm{~min}$, and a final extension at $72^{\circ} \mathrm{C}$ for $2 \mathrm{~min}$. PCR amplicon were kept at $4^{\circ} \mathrm{C}$.

\section{DGGE Primers used for archaea}

Ar3F (5'-TTC CGG TTG ATC CTG CCG GA-3') (Zwiettering et al. 1994); Ar4F (5'-TCY GGT TGA TCC TGC CRG-3') (Hershberger et al., 1996); 21F (5'-TTC CGG TTG ATC CTG CCG GA) (Abdallah et al. 2016); 958R (5'-YCC GGC GTT GAN TCC AAT T-3') (Abdallah et al. 2016); Ar9R (5'-CCC GCC AAT TCC TTT AAG TTT C3'); 915R (5'-GTG CTC CCC CGC CAA TTC C-3') (Abdallah et al. 2016); 69F (5'-TAA GCC ATG CAA GTC GAC G-3') (Leadbettter \& Breznak 1996); 344F *5'-ACG GGG YGC AGC AGG CGC GA TCG CGC CTG CTC CCC GT-3' (The GC-clamp used, 5'-CGC CCG CCG CGC GCG GCG GGC GGG GCG GGG GCA CGG GGG G-3', was attached to the $5^{\prime}$-end of the $344 \mathrm{~F}$ primer)(Raskin et al. 1994). 
DGGE Primers used for most Bacteria and Archaea: 1492R (5'-GGY TAC CTT GTT ACG ACT T-3') (Leadbettter \& Breznak 1996).

DGGE was performed using a Dcode Universal Mutation Detection System (Bio Rad Laboratories, Hercules, CA, USA), following system recommendations (Muyzer et al. 1993). Electrophoresis was performed at a constant voltage for $4 \mathrm{~h}$ (archaea) and $8 \mathrm{~h}$ (bacteria). Gels were stained with silver nitrate (Sanguinetti et al. 1994), while ethidium bromide $(0.5 \mu \mathrm{g} / \mathrm{mL})$ was used to obtain bands for subsequent sequencing. Excised gel bands were re-amplified (Valdebenito-Rolack et al. 2011), quantified and sequenced (Macrogen, Korea). Images (densitograms) were analysed by Quantity One software, BioRad version 4.2.3 using WPGAMA for cluster analysis (Chen et al. 2017, Putra et al. 2020).

\section{Estimation of $\left(\mathrm{NH}_{3}\right)$-mMPA consortia growth kinetics in biofilm}

The growth kinetics of $\left(\mathrm{NH}_{3}\right)$-mMPA in biofilms were estimated using the Gompertz model as described by Zwietering et al. (1994). Data were adjusted to the model by nonlinear regression and the most useful model was selected (Sokal \& Rohlf 1968). To obtain the maximum specific growth rate $(\mu)$, lag phase duration $(\lambda)$ and maximum count (A), results free R software for Windows was used. To compare the control reactor with the experimental reactor, t-tests were performed for independent groups, with a statistical significance of 0.005 using the SYSTAT Software package. Normal distribution was assumed, given that the measurements were performed in triplicate.

NUCLEOTIDE ACCESSION NUMBERS: The archaeal sequences obtained and described in this study of mMPA rRNA 16S gene sequence data were submitted to the NCBI GenBank database under accession numbers: EU544305, EU544306 and EU544307.

\section{PHYLOGENETIC ANALYSIS}

Sequences for selected clones in this study have been submitted to NCBI/GenBank. These were aligned with the NCBI nucleotide database using BLAST (Altschul et al. 1997), as those sequences were at least $90 \%$ identical and above. To compare the diversity of OTU in CR and TR in different phases of the bioreactors, a multiple alignment was performed using ClustalW (Mount 2004). Phylogenetic trees were calculated with MEGA4 software (Tamura et al. 2007), using the Kimura two-parameter correction and the Neighbour-Joining method.

\section{Results And Discussion}

\section{Isolation and growth kinetics of ammonia tolerant consortia $\left(\mathrm{NH}_{3}\right)$-mMPA biofilm}

Ammonia tolerant consortia, $\left(\mathrm{NH}_{3}\right)$-mMPA, were isolated from the reactor enriched with mMPA communities. Consortia showed a Methanosarcinaceae MPA family prevalence. Consortia were able to grow in a planktonic phase at $848.8 \mathrm{mg} \mathrm{NH}_{3} / \mathrm{L}$ with methane representing a mean of approximately $70 \%$ of the produced biogas. $\left(\mathrm{NH}_{3}\right)$-mMPA consortia were inoculated into vials with ceramic spheres as 
support for 20 days, allowing biofilm formation. Growth kinetics determined by the Gompertz model showed $a \lambda$ of $3.7 d$ (days) and $\mu_{m}$ of $0.67 d^{-1}$, with $r^{2}=0.95$ (Fig. 1A). In addition, methane production was monitored during biofilm formation. Methane peaked at $80 \%$ of total biogas after 20 days of incubation. A time lag of 5-6 days was observed in methane production. By performing SEM analysis, $\left(\mathrm{NH}_{3}\right)$-mMPA consortia were detected on the support surfaces after 4 days of incubation, consistent with the kinetic growth data that predicted micro-colony formation after 20 days of incubation (Fig. 1B).

\section{Design of an anaerobic biofilm enriched with $\left(\mathrm{NH}_{3}\right)$-mMPA under $\mathrm{NH}_{3}$ shock}

After a full year of operation, the control bioreactor (CR) showed a decrease of approximately $80 \%$ in TOC (Fig. 2A), with $85 \%$ methane content in the produced biogas. The methane production curve obtained for the treatment bioreactor (TR) gradually increased, approaching $70 \%$ of the biogas produced in the first 50 days (Fig. 2B). The alkalinity alpha factor remained below 0.3 in both reactors, TOC consumption varied between $80 \pm 20 \%$ in $C R$ and $62 \pm 17 \%$ in TR. Methane content in the biogas ranged from $86 \pm 8 \%$ in $C R$, and $81 \pm 18 \%$ in TR (Fig. $2 \mathrm{~A}$ and $2 \mathrm{~B}$ ).

\section{Morphological and genotyping characterization of $\left(\mathrm{NH}_{3}\right)$-mMPA consortia and ammonia Tolerant biofilm}

To determine the microbial morphologies present in $\left(\mathrm{NH}_{3}\right)$-mMPA consortia, concentrated planktonic cultures and ceramic support fragments were observed by SEM. Sarcina morphotypes characteristic of Methanosarcinaceae were found (Fig. 1B). Analysis of the 16S rDNA from $\left(\mathrm{NH}_{3}\right)$-mMPA consortia revealed that gene sequences were grouped with Methanosarcinaceae members (Methanosarcinaceae, Methanosarcinales). Phylogenetic relationships of archaeal 16S rDNA partial sequences (EU544306; EU544307), archaeal mMPA ammonium tolerant strain 16S rDNA partial sequence (EU544305) and methanogenic species sequences from the Gene bank show that mMPA sequence EU544305 (868 bp), was grouped in the Methanomethylovorans genus. This is because it showed higher similarities with uncultured archaeon (99\%) and Methanomethylovorans hollandica (Lomans 1999) (98\%), and two different species of Methanosarcina genera which were predominant components of the consortia, and similar to cloned sequences. EU544306 (547 bp), uncultured Methanosarcina sp. clone HUB A5, and EU544307 (521 bp), were grouped into the Methanosarcina genus, showing high similarity with Methanosarcina sp. (95\%) and Methanosarcina baltica (von Klein 2002) (95\%). When a BLAST analysis compared the sequences with stored species Types of uncultured Methanosarcina sp. clone HUB A5, this is located near Methanosarcina baltica in a phylogenetic tree at a Neighbor Joining distance of 0.05 (not shown). M. baltica is an archaeon isolated from anoxic layers of sediment in the Baltic Sea that grows fast in marine culture, in methylamines, methanol, and acetate (vonKlein et al. 2002). Uncultured Methanosarcina sp. clone HUB A6 sequence EU544307 was also grouped in the Methanosarcina genus, showing high similarity to Methanosarcina acetivorans (Sowers 1984) (93\%) and uncultured Methanosarcina sp. (92\%). Uncultured Methanosarcina sp. clone HUB A6 is located near Methanosarcina acetivorans in a phylogenetic tree at a Neighbor Joining distance of 0.2 (not shown), also described in anoxic marine environments and found as a single cell in marine cultures (Maeder et al. 2006). 
Microbiological and molecular description of biofilm in bioreactors: Ammonia concentration in both bioreactor influents ranged between 37.7 and $128 \mathrm{mg} \mathrm{NH}_{3}-\mathrm{N} / \mathrm{L}$ until day 152, when both bioreactors were subjected to ammonia shock, increasing ammonia concentrations to $755 \mathrm{mg} \mathrm{NH}_{3}-\mathrm{N} / \mathrm{L}$. Between day 180 and 208, ammonia concentrations returned to average levels (37.2-41.1 $\mathrm{mg} \mathrm{NH}_{3}-\mathrm{N} / \mathrm{L}$ ). Significant differences in ammonia concentration were observed in phases $C$ and $D$ in both TR and CR effluent outputs (Fig. 2A and 2B). The experimental bioreactor showed a lower concentration of ammonia residual (137-184 $\mathrm{mg} \mathrm{NH}_{3} \mathrm{~L}^{-1}$ ) when compared with the control bioreactor (327-128 $\mathrm{mg} \mathrm{NH}_{3} \mathrm{~L}^{-1}$ ). Shock $\mathrm{NH}_{3}-\mathrm{N}$ effects in $\mathrm{CR}$ and TR are shown in Fig. 2A and 2B, respectively. Methanation in $\mathrm{CR}$ began at $90 \%$, dropping to $70 \%$ during ammonia shock (Fig. 2A). A different response was observed in TR, where no significant variations were observed during the ammonia shock, reaching methanation levels above $90 \%$ throughout the experiment (t-test, $p$ 0.0005-0.01) (Fig. 2B). In both cases (CR and TR), correlations between the percentage of TOC consumed and the concentration of methane produced were significant $\left(r^{2}: 0.72 p \leq 0.05\right.$ for CR, and $r^{2}=0.77 p \leq 0.05$ for TR) (Fig. 2). Production of methane specific was determined based on biomass as volatile suspended solids (VSS) were registered in both reactors. In CR, a production of $0.32 \pm 0.04 \mathrm{~mL} \mathrm{CH} / \mathrm{g}$ (VSS * d) was registered, while TR showed a production of $0.65 \pm$ $0.08 \mathrm{~mL} \mathrm{CH}_{4} / \mathrm{g}(\mathrm{VSS} * \mathrm{~d})$, this activity was re-controlled post ammonia shock where it was found a production of $0.30 \pm 0.05 \mathrm{~mL} \mathrm{CH} 4 / \mathrm{g}$ (VSS * d) in CR and $0.38 \pm 0.04 \mathrm{~mL} \mathrm{CH}_{4} / \mathrm{g}(\mathrm{VSS} * \mathrm{~d})$ in TR. Increased methanogenic activity per biomass unit from day 152 to 166 was 20.5 -fold higher in TR when compared to $\mathrm{CR}$, which indicates that methanogenic archaea maintained their activity under ammonia shock conditions.

FIGURE 2. Total Organic Carbon consumption, methanization and ammonia concentration in an anaerobic filter type reactor enriched with mMPA. 2A. CR. 2B. TR. Phase A: CR anaerobic biofilm development with ammonia operating range of 27.45-75 $\mathrm{mg} \mathrm{NH}_{3}-\mathrm{N} / \mathrm{L}$; Phase B. Reactor acclimatization- Initial phase bioreactor functioning. Acclimatization at 37.7-128 $\mathrm{mg} \mathrm{NH}_{3}-\mathrm{N} / \mathrm{L}$. Phase C: Ammonia shock at $755 \mathrm{mg} \mathrm{NH}_{3}-\mathrm{N} / \mathrm{L}$, Phase D: Final phase bioreactor functioning, reactor recovery from 37.1 to $41.2 \mathrm{mg} \mathrm{NH}_{3}-\mathrm{N} / \mathrm{L}$. $\square$ - \% Total Organic Carbon (TOC) consumption; - $\square-\%$ methane; - - - $\mathrm{NH}_{3}$ input concentration; - $-\mathrm{NH}_{3}$ output concentration.

When comparing the first 100 days of both reactors, the control bioreactor consumed significantly more TOC than the experimental bioreactor (t-test, $p<0.0001-0.007)$. Methane production measure by gas chromatography was also significantly higher in the CR $(89.48 \%-95 \%)$ when compared to the TR (29\% $-75 \%)(p<0.0001-0.029)$. These differences diminished from day 54 to 82 (Fig. $2 \mathrm{~A}$ and 2B). During and after the ammonia shock, (phase $C$ - day 152 to 208), a higher consumption of TOC was observed in both bioreactors, although it was significantly higher in the TR until day 180 , after which it decreased significantly to $65.78 \%$ on day 208 . Methane production in the TR remained above $90 \%$, significantly higher than in the $\mathrm{CR}(p<0.0005-0.0417)$, which showed a methane production that fluctuated between $69 \%-86 \%$ (Fig. 2A and 2B). Significant differences (t-test, $a \leq 0.05$ ) were observed for both methane production and TOC concentrations when comparing the $\mathrm{CR}$ and TR during the ammonia shock step. Figures $2 \mathrm{~A}$ and $2 \mathrm{~B}$ show how the ammonia shock caused a significant decline ( $\mathrm{t}$-test, $\mathrm{a}=0.05$ ) in 
methane production and TOC consumption in the CR. These results clearly indicate that the TR was resistant to the deleterious effect of ammonia, as the mMPA biofilm community was able to maintain its methanogen activity even under high ammonia concentrations.

Bands in the gel were conspicuous in phase B, the acclimatization phase (Fig. 3A, lane B), but tended to diminish in phase $C$, the ammonia shock, (Fig. 3A, lane $C$ ). However, the abundance of archaea increased between phase $B$, the recovery phase, and phase $D$, the final phase (Fig. 3A, lane D). Besides, lower archaea biodiversity was observed in the $\mathrm{CR}$ throughout the profile when compared with TR biofilm (Fig. 3C). Moreover, it was observed that $\left(\mathrm{NH}_{3}\right)$-mMPA enriched biofilm produced fewer bands in the bacteria domain in the $C R$ than biofilm enriched with mMPA tolerant to ammonia (Fig. 3B, lanes B, $C$ and D). However, $16 \mathrm{~S}$ rDNA bacterial profile similarities were higher in the CR than in the TR. Similarities were lower for archaea than bacteria, as shown in Fig. 3C and 3D.

Figure. 3.A. DGGE profiles of archaea. Gel bands recovered from 16S rDNA gels were sequenced and identified as EU544305 Methanomethylovorans sp., EU544306 and EU544307; two different species belonging to Methanosarcina sp. B. DGGE profiles of bacteria. C. Cluster analysis (WPGMA) using data from DGGE profiles of archaea in anaerobic biofilm to assess the similarity of taxonomic composition of consortia assigned to treatment of industrial waste rich in proteins, obtained from the control reactor (CR). D. Treatment Reactor (TR) lanes. B lanes- phase B, initial acclimatization at 37.7-128 mg NH $\mathrm{H}_{3}-\mathrm{N} / \mathrm{L}$; C lanes- phase $\mathrm{C}$, ammonia shock at $755 \mathrm{mg} \mathrm{NH}_{3}-\mathrm{N} / \mathrm{L}$; D lanes- phase $\mathrm{D}$, final reactor recovery from 37.1 to $41.2 \mathrm{mg} \mathrm{NH}_{3}-\mathrm{N} / \mathrm{L}$.

This study demonstrates that efficient wastewater treatment and stable methane production can be achieved under high ammonia concentrations by using anaerobic biofilms formed in fixed bed reactors containing $\left(\mathrm{NH}_{3}\right)$-mMPA (ammonia tolerant archaea biofilms).

Zheng et al. (2015) demonstrate that the selection of a suitable support for fixed-bed reactors is crucial for the anaerobic digestion of ammonium-rich livestock wastes, since they found that using zeolites as support they achieve a methane production over $80 \%$, compared to other types of support, which is comparable to that shown in this research. $\mathrm{NH}_{3}$-tolerant microbial consortium, defined as a microbial community composed of archaea and bacteria, give rise to long-term stable communities whose tolerance to ammonia stress can be increased with an acclimated consortium. The main components (archaea) found in this study, of selected tolerant consortia shared general characteristics with the Methanosarcinaceae family, with the mMPA EU544305 sequence related to the Methanomethylovorans genus, and the other two sequences (EU544306 and EU544307) related to the Methanosarcina genus, the first one of which is considered an obligate methylotrophic methanogen (Supplementary Material SI 1. to SI 3.). Members of Methanosarcinaceae have been found in a wide variety of anaerobic environments where methane is produced, can grow on a diversity of substrates, and represent the most versatile group of Archaea (Oren 2014). The predominant archaea throughout the experiment were Methanosarcina and Methanomethylovorans (He et al. 2017; Cadavid-Rodríguez et al. 2019). Some researchers consider these species to be keystone species. For example, Methanosarcina acetivorans (Galagan et al. 2002), is a 
unique species which may have a wide range of metabolisms that support the reactor's operation under ammonia shock.

In a study by Wu and Song (2021), adding inoculum through anaerobic co-digestion of waste activated sludge (WAS) and fish waste (FW), high methane production rates were obtained with mixtures of $1.5 \%$ and $3 \%$ of $\mathrm{FW}$, but methanogenesis was inhibited with an addition of $6 \%$ of $\mathrm{FW}$ or higher, finding a high accumulation of ammonia and fatty acid. In a similar trial, Cadavid-Rodríguez et al. (2019) found that when using from $1.5 \%$ of FW in anaerobic digestion, methanogenesis is inhibited. Thus, the alternative of enriching the inoculum with ammonia-tolerant mMPA is attractive and feasible to avoid the inhibition of methanogenesis in the treatment of protein-rich fishery waste.

Furthermore, the analyses of the microbial community carried out by Wu \& Song (2021) showed that methane production was dominated by hydrogenotrophic and methylotrophic methanogenic archaea, which is to be expected since fishery residues are rich in methylated amines, which would favour the growth and maintenance of the Ammonia tolerant mMPA consortia.

Physiological studies of this strain have reported that it tolerates $\mathrm{NaCl}$ concentrations of $100 \mathrm{mM}$. In this study, the $\mathrm{NH}_{3}$ tolerant consortia were able to grow and maintain constant methanogenic activity at 400 $\mathrm{mM} \mathrm{NaCl}$, a characteristic that favours their use for fishery waste treatment at high salt concentrations (Aloui et al. 2009, Chen et al. 2018, He et al. 2017). Because salinity has been reported to deteriorate removal performance, activated sludge characteristics, and change microbial community in anaerobic reactors (Chen et al., 2017; He et al., 2017).

We identified a strong relationship between reactor performance and abundance of Methanosarcina cells. Until day 398 (750 FAN mg/L; 6000 TAN mg/L), highly active Methanosarcina cells were identified in large multicellular structures (clusters). Calli et al. (2005) found an abundance of Methanosarcina species at high ammonia concentrations (160-747 mg).

The experimental bioreactor showed constant low values of ammonia in the output effluent after an ammonia shock when compared to the control bioreactor. Similar results have been previously reported (Dai et al. 2016). The $16 S$ rDNA profile of archaea and bacteria obtained by PCR-DGGE shifted at OTU (Operational Taxonomic Units) composition, confirming that an acetoclastic methanogenesis dominated acetate utilization in the bioreactor. Galagan et al. (2002) described the metabolic and physiological diversity of Methanosarcina acetivorans, suggesting that the formation of multicellular structures (cell envelope and extracellular matrix) is an adaptation to stress and likely plays an important role in the ability of Methanosarcina to colonise diverse environments. This species metabolises a broad spectrum of carbon compounds into methane, a process controlled by different methanogenesis genes. Individual copies of the duplicated genes may display differential regulation and kinetic properties, allowing the species to change between substrates, consistent with the reported plasticity that Methanosarcina species show in nature (Angelidaki et al. 2011), an important characteristic that allows the community to tolerate stress. High bacterial biodiversity was observed in the communities, but we did not find 
significant differences between these communities. This idea has been expressed before in studies on stability in an anaerobic bioreactor (Fernández et al. 2000), where bacteria were found in the biofilm, even under stress. Nevertheless, according to our results, when the communities were exposed to changing conditions, the bacterial activity was modified, and archaea did not exhibit significant differences in abundance.

Our coastal zone is characterized by high primary productivity favoured by wind predominance and marine oceanographic current system in the South Eastern Pacific Ocean, that produce constant upwelling and for decades or centuries had been registered major fish strandings (Hernandez-Miranda et al. 2010, 2012, 2017). It is probable that an unknown endemic rich microbial ammonia methanogenic (bacteria and archaea) community potentially had evolved associated both sea water column and sediments because high protein content product of strandings. This potential microbial community sampled from effluent industrial fishery was used in the bioreactor and bioaugmented in the treatment bioreactor and our objective was characterized archaea components.

\section{Declarations}

To be used for life science journals + articles with biological applications

- Funding: the research was supported by internal funds from the Universidad de Concepción obtained by Fidelina Gonzalez. DIC UDEC 203.031.095-1.0. Ammonia effects on taxonomic diversity of methanogenic Archaea in anaerobic biofilms used to purify industrial discharges high in protein. DIUC-Ordinario, 10-2003, 10-2005. DAAD grant.

- Conflicts of interest/Competing interests: Not applicable

- Ethics approval: All authors subscribe to the Singapore Statement of Ethics for Life Science Work.

- Consent to participate: All authors give their consent to participate in this article and in general in the research presented.

- Consent for publication: All authors give their consent to participate in this article and in general in the research presented.

- Availability of data and material: The data used for this article is available to be requested by the reviewers if they deem it appropriate.

- Code availability: Not aplicable

\section{Author Contribution}

Manuel Alarcón-Vivero: Data curation, Formal analysis, Investigation, Methodology, Writing - original draft. Writing - review \& editing

Nathaly Ruiz-Tagle: Conceptualization, Formal analysis, Investigation, Writing - original draft 
Fidelina Gonzalez: Conceptualization, Data curation, Formal analysis, Writing - original draft

Paz Jopia-Contreras: Conceptualization, Investigation, Methodology

Estrella Aspé: Conceptualization, Formal analysis, Investigation

Homero Urrutia Briones: Conceptualization, Formal analysis, Supervision, Visualization

Katherine Sossa Fernandez: Conceptualization, Funding acquisition, Project administration, Supervision, Visualization

\section{ACKNOWLEDGEMENTS}

DIC UDEC 203.031.095-1.0. Ammonia effects on taxonomic diversity of methanogenic Archaea in anaerobic biofilms used to purify industrial discharges high in protein. DIUC-Ordinario, 10-2003, 10-2005. DAAD grant.

\section{References}

1. Abdallah MB, Karray F, Mhiri N, Mei N, Quéméneur M, Cayol JL, Erauso G, Tholozan JL, Alazard D, Sayadi S (2016) Prokaryotic diversity in a Tunisian hypersaline lake. Chott El Jerid Extremophiles 20:125-138. https://10.1007/s00792-015-0805-7

2. Aloui F, Khoufi S, Loukil S, Sayadi S (2009) Performances of an activated sludge process for the treatment of fish processing saline wastewater. Desalination 246(1-3):389-396. doi:10.1016/j.desal.0000.00.000

3. Altschul SF, Madden TL, Schäffer AA, Zhang J, Zhang Z, Miller W, Lipman DJ (1997) Gapped BLAST and PSI-BLAST: a new generation of protein database search programs. Nucleic Acids Research 25(17): 3389-3402 https://doi.org/10.1093/nar/25.17.3389

4. Anderson TF (1951) Techniques for the preservation of three-dimensional structure in preparing specimens for the electron microscope. Transactions of the New York Academy of Sciences 13 (4 Series II):130-134 https://doi.org/10.1111/j.2164-0947.1951.tb01007.x

5. Angelidaki I, Karakashev D, Batstone DJ, Plugge CM, Stams AJ (2011) Biomethanation and its potential. Methods Enzymol 494:327-351. https://doi.org/10.1016/B978-0-12-385112-3.00016-0

6. APHA (1992) Standard methods for the examination of waste and wastewater. American Public Health Association, New York

7. Beck BR, Holzapfel W, Hwang CW, Do HK (2013) Bacterial Community Structure Shift Driven by Salinity: Analysis of DGGE Band Patterns from Freshwater to Seawater of Hyeongsan River, Korea. Journal of Life Science 23(3):406-414. https://doi.org/10.5352/JLS.2013.23.3.406

8. Cadavid-Rodríguez LS, Vargas-Muñoz MA, Plácido J (2019) Biomethane from fish waste as a source of renewable energy for artisanal fishing communities. Sustainable Energy Technologies and Assessments 34: 110-115 https:// doi.org/10.1016/j.seta.2019.05.006 
9. Calli B, Mertoglu B, Inanc B, Yenigun O (2005) Methanogenic diversity in anaerobic bioreactors under extremely high ammonia levels. Enzyme and Microbial Technology 37: 448-455 https://doi.org/10.1016/j.enzmictec.2005.03.013

10. Chen Y, He H, Liu H, Li H, Zeng G, Xia X, Yang C (2018) Effect of salinity on removal performance and activated sludge characteristics in sequencing batch reactors, Bioresource Technology 249: 890899. https://doi.org/10.1016/j.biortech.2017.10.092

11. Chen WY, Kraková L, Wu JH, Pangallo D, Jeszeová L, Liu B, Yasui H (2017) Community and proteomic analysis of anaerobic consortia converting tetramethylammonium to methane. Archaea, (3) 1-14. https://doi.org/10.1155/2017/2170535

12. Clegg SL, Whitfield M (1995) A chemical model of seawater including dissolved ammonia and the stoichiometric dissociation constant of ammonia in estuarine water and seawater from -2 to $40^{\circ} \mathrm{C}$. Geochimica et Cosmochimica Acta 59 (12):2403-2421 https://doi.org/10.1016/00167037(95)00135-2

13. Dai X, Yan H, Li N, He J, Ding Y, Dai L, Dong B (2016) Metabolic adaptation of microbial communities to ammonium stress in a high solid anaerobic digester with dewatered sludge. Sci Rep 6:28193. https://doi.org/10.1038/srep28193

14. Dar SA, Kuenen JG, Muyzer G (2005) Nested PCR-denaturing gradient gel electrophoresis approach to determine the diversity of sulfate-reducing bacteria in complex microbial communities. Appl Environ Microbiol 71(5):2325-2330. https://doi.org/10.1128/AEM.71.5.2325-2330.2005

15. Galagan JE, Nusbaum C, Roy A, Endrizzi MG, Macdonald P, FitzHugh W, Brown A (2002) The genome of $M$. acetivorans reveals extensive metabolic and physiological diversity. Genome Res 12(4):532542. https://doi.org/10.1101/gr.223902

16. Gupta P, Shekhar R, Sachan A, Vidyarthi AS, Gupta A (2012) A re-appraisal on intensification of biogas production. Renew Sustain Energy Rev 16:4908-4916. https://doi.org/10.1016/j.rser.2012.05.005

17. Hernández-Miranda E, Quiñones RA, Aedo G, Valenzuela A, Mermoud N, Román C, Yañez F (2010) A major fish stranding caused by a natural hypoxic event in a shallow bay of the eastern South Pacific Ocean. J Fish Biol 76(7):1543-1564. doi:10.1111/j.1095-8649.2010.02580.x

18. Hernández-Miranda E, Veas R, Anabalón V, Quiñones RA (2017) Short-term alteration of biotic and abiotic components of the pelagic system in a shallow bay produced by a strong natural hypoxia event. Plos one 12(7):e0179023

19. Hernández-Miranda E, Veas R, Labra FA, Salamanca M, Quiñones RA (2012) Response of the epibenthic macrofaunal community to a strong upwelling-driven hypoxic event in a shallow bay of the southern Humboldt Current System. Mar Environ Res 79:16-28. doi:10.1016/j.marenvres.2012.04.004

20. He H, Chen Y, Li X, Cheng Y, Yang C, Zeng G (2017) Influence of salinity on microorganisms in activated sludge processes: a review. International Biodeterioration Biodegradation 119:520-527. http://dx.doi.org/10.1016/j.ibiod.2016.10.007 
21. Hershberger KL, Barns SM, Reysenbach AL, Dawson SC, Pace NR (1996) Wide diversity of Crenarchaeota. Nature 384(6608):420. https://doi.org/10.1038/384420a0

22. Hobbie JE, Daley RJ, Jasper S (1977) Use of nucleopore filters for counting bacteria by fluorescence microscopy. Applied and Environmental Microbiology 33 (5):1225-1228

23. Jurgens G, Lindström K, Saano A (1997) Novel group within the kingdom Crenarchaeota from boreal forest soil. Applied and Environmental Microbiology 63 (2):803-805

24. Kato S, Watanabe K (2010) Ecological and Evolutionary Interactions in Syntrophic Methanogenic Consortia. Microbes Environments 25(3):145-151. https://doi.org/10.1264/jsme2.ME10122

25. Kayhanian M (1999) Ammonia Inhibition in High-Solids Biogasification: An Overview and Practical Solutions. Environ Technol 20(4):355-365. https://doi.org/10.1080/09593332008616828

26. Maeder DL, Anderson I, Brettin TS, Bruce DC, Gilna P, Han CS, Lapidus A, Metcalf W, Saunders E, Tapia R, Sowers KR (2006) The Methanosarcina barkeri genome: comparative analysis with Methanosarcina acetivorans and Methanosarcina mazei reveals extensive rearrangement within methanosarcinal genomes. Journal of bacteriology 188(22): 7922-7931. https://doi.org/10.1128/JB.01858-06

27. Mohan SV, Rao NC, Prasad KK, Sarma PN (2005) Bioaugmentation of an anaerobic sequencing batch biofilm reactor (AnSBBR) with immobilized sulphate reducing bacteria (SRB) for the treatment of sulphate bearing chemical wastewater. Process Biochem 40:2849-2857. https://doi.org/10.1016/j.procbio.2004.12.027

28. Mount D (2004) Bioinformatics: Sequence and Genome Analysis Cold Spring Harbor Laboratory Press, Cold Spring Harbor, NY

29. Muyzer G, de Waal EC, Uittierlinden AG (1993) Profiling of complex microbial populations by denaturing gradient gel electrophoresis analysis of polymerase chain reaction-amplified genes coding for 16S rRNA. Appl Environ Microbiol 59(3):695-700

30. Omil F, Mendez R, Lema JM (1995) Anaerobic treatment of saline wastewaters under high sulphide and ammonia content. Biores Technol 54:269-278. https://doi.org/10.1016/0960-8524(95)00143-3

31. Oren A (2014) The Family Methanosarcinaceae. In: Rosenberg E, DeLong EF, Lory S, Stackebrandt E, Thompson F (eds) The Prokaryotes. Springer, Berlin, Heidelberg

32. Pham CH, Triolo JM, Cu TTT, Pedersen L, Sommer SG (2013) Validation and recommendation of methods to measure biogas production potential of animal manure. Asian-Australasian Journal of Animal Sciences 26(6):864-873. https://doi.org/10.5713/ajas.2012.12623

33. Procházka J, Dolejš P, Máca J, Dohányos M (2012) Stability and inhibition of anaerobic processes caused by insufficiency or excess of ammonia nitrogen. Applied Microbiology and Biotechnology 93 (1): 439-447. https://doi.org/10.1007/s00253-011-3625-4

34. Putra AA, Watari T, Maki S, Hatamoto M, Yamaguchi T (2020) Anaerobic baffled reactor to treat fishmeal wastewater with high organic content. Environmental Technology Innovation 17:100586. https://doi.org/10.1016/j.eti.2019.100586 
35. Raskin L, Stromley JM, Rittmann BE, Stahl, DA (1994) Group-specific16S rRNA hybridization probes to describe natural communities of methanogens. Applied and Environmental Microbiology 60 (4):1232-1240

36. Sanguinetti CJ, Dias Neto E, Simpson AJ (1994) Rapid silver staining and recovery of PCR products separated on polyacrylamide gels. Biotechniques 17(5):914-921

37. Sokal R, Rohlf F (1968) Biometría, Principios y Métodos estadísticos para la investigación biológica. Trad de Biometrics por ML Leon, Malaga

38. Sossa K, Alarcón M, Aspé E, Urrutia H (2004) Effect of ammonia on the methanogenic activity of methylaminotrophic methane producing Archaea enriched biofilm. Anaerobe 10(1):13-18. https://doi.org/10.1016/j.anaerobe.2003.10.004

39. Sung S, Liu T (2003) Ammonia inhibition on thermophilic anaerobic digestion. Chemosphere 53(1):43-52. https://doi.org/10.1016/S0045-6535(03)00434-X

40. Tamura K, Dudley J, Nei M, Kumar S (2007) MEGA4: Molecular Evolutionary Genetics Analysis (MEGA) Software Version 4.0. Mol Biol Evol 24(8):1596-1599

41. Urrutia H, Vidal R, Baeza M, Aspé E (1999) Effect of fishing industries effluents pH and organic load on the methanogenic bacteria biofilm developed over support in fixed biomass reactor. Anaerobe 5(3):325-327. https://doi.org/10.1006/anae.1999.0301

42. Valdebenito-Rolack EH, Araya TC, Abarzua LE, Ruiz-Tagle NM, Sossa KE, Aroca GE, Urrutia HE (2011) Thiosulphate oxidation by Thiobacillus thioparus and Halothiobacillus neapolitanus strains isolated from the petrochemical industry. Electronic Journal of Biotechnology 14(1): 7-8. https://doi.org/10.2225/vol14-issue1-fulltext-10

43. Vidal G, Carvalho A, Mendez R, Lema JM (2000) Influence of the content in fats and proteins on the anaerobic biodegradability of dairy wastewaters. Biores Technol 74(3):231-239. https://doi.org/10.1016/S0960-8524(00)00015-8

44. von Klein D, Arab H, Völker H, Thomm M (2002) Methanosarcina baltica, sp. nov., a novel methanogen isolated from the Gotland Deep of the Baltic Sea. Extremophiles 6(2):103-110. https://doi.org/10.1007/s007920100234

45. Wu Y, Song K (2021) Anaerobic co-digestion of waste activated sludge and fish waste: Methane production performance and mechanism analysis. J Clean Prod 279:123678. https://doi.org/10.1016/j.jclepro.2020.123678

46. Zheng H, Li D, Stanislaus MS, Zhang N, Zhu Q, Hu X, Yang Y (2015) Development of a bio-zeolite fixed-bed bioreactor for mitigating ammonia inhibition of anaerobic digestion with extremely high ammonium concentration livestock waste. Chem Eng J 280:106-114. http://dx.doi.org/10.1016/j.cej.2015.06.024

47. Zwietering M, De Wit JC, Cuppers AM, Van T, Riet K (1994) Microbiology Modeling of Bacterial Growth with Shifts in Temperature. Appl Environ Microbiol 60:204-213

\section{Figures}




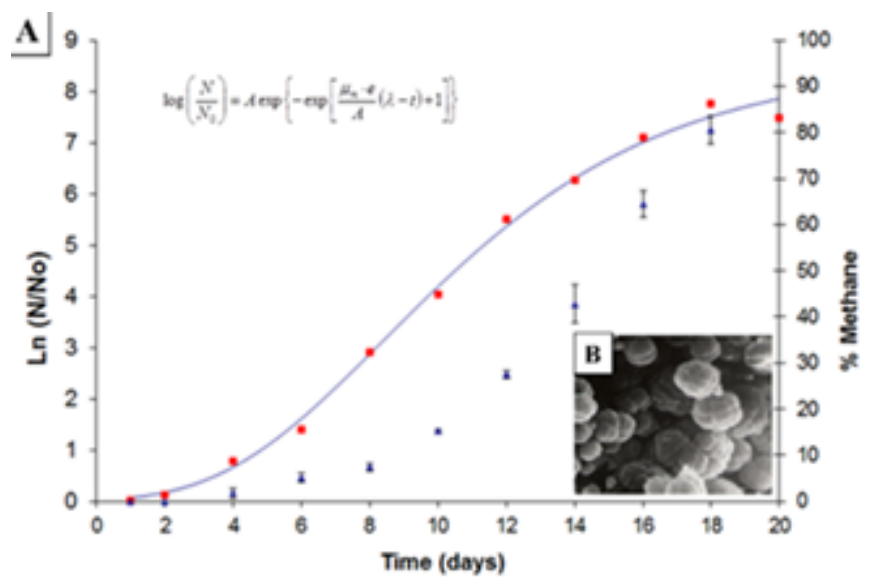

Model predicted growth kinetics

Experimental growth kinetic values

A $\%$ Methane

\section{Figure 1}

A. Ammonia-tolerant isolated Methanosarcinaceae biofilm growth kinetics on ceramic supports at $\lambda 3.7$ days and $\mu=0.67 \mathrm{~d}-1$ ( $r 2$ 0.95). Experimental values; - Values predicted by Gompertz model; $\boldsymbol{\Delta}$ methane in biogas (\%). Bars represent standard deviation of average methane \%. B. Image inside the graphic is a Microphotograph of isolated methanogenic ammonia tolerant Archaea (mMPA), Methanomethylovorans sp. (Methanosarcinaceae, Methanosarcinales) (5000X).
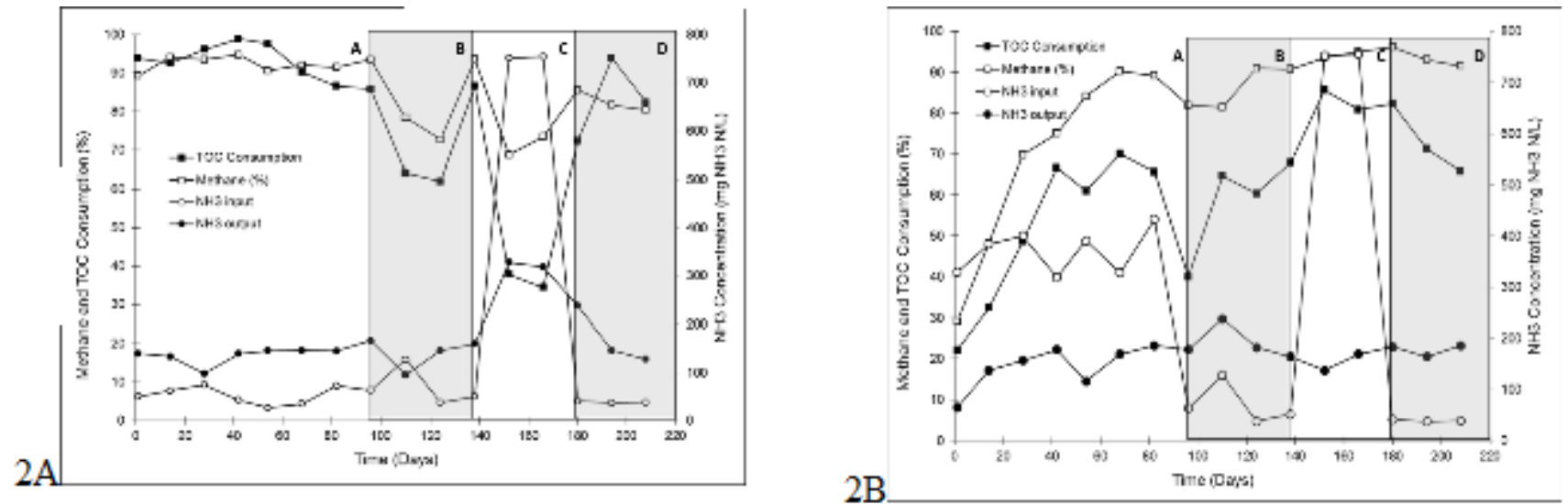

Figure 2

Total Organic Carbon consumption, methanization and ammonia concentration in an anaerobic filter type reactor enriched with mMPA. 2A. CR. 2B. TR. Phase A: CR anaerobic biofilm development with ammonia operating range of 27.45 - 75 mg NH3-N/L; Phase B. Reactor acclimatization- Initial phase bioreactor functioning. Acclimatization at 37.7 -128 mg NH3-N/ L. Phase C: Ammonia shock at $755 \mathrm{mg} \mathrm{NH3-N/L,}$ Phase D: Final phase bioreactor functioning, reactor recovery from 37.1 to $41.2 \mathrm{mg} \mathrm{NH3-N/L.} \mathbf{\square}$ - \% Total Organic Carbon (TOC) consumption; - $\square$-\% methane; -- -- NH3 input concentration; --0-- NH3 output concentration. 
A

B

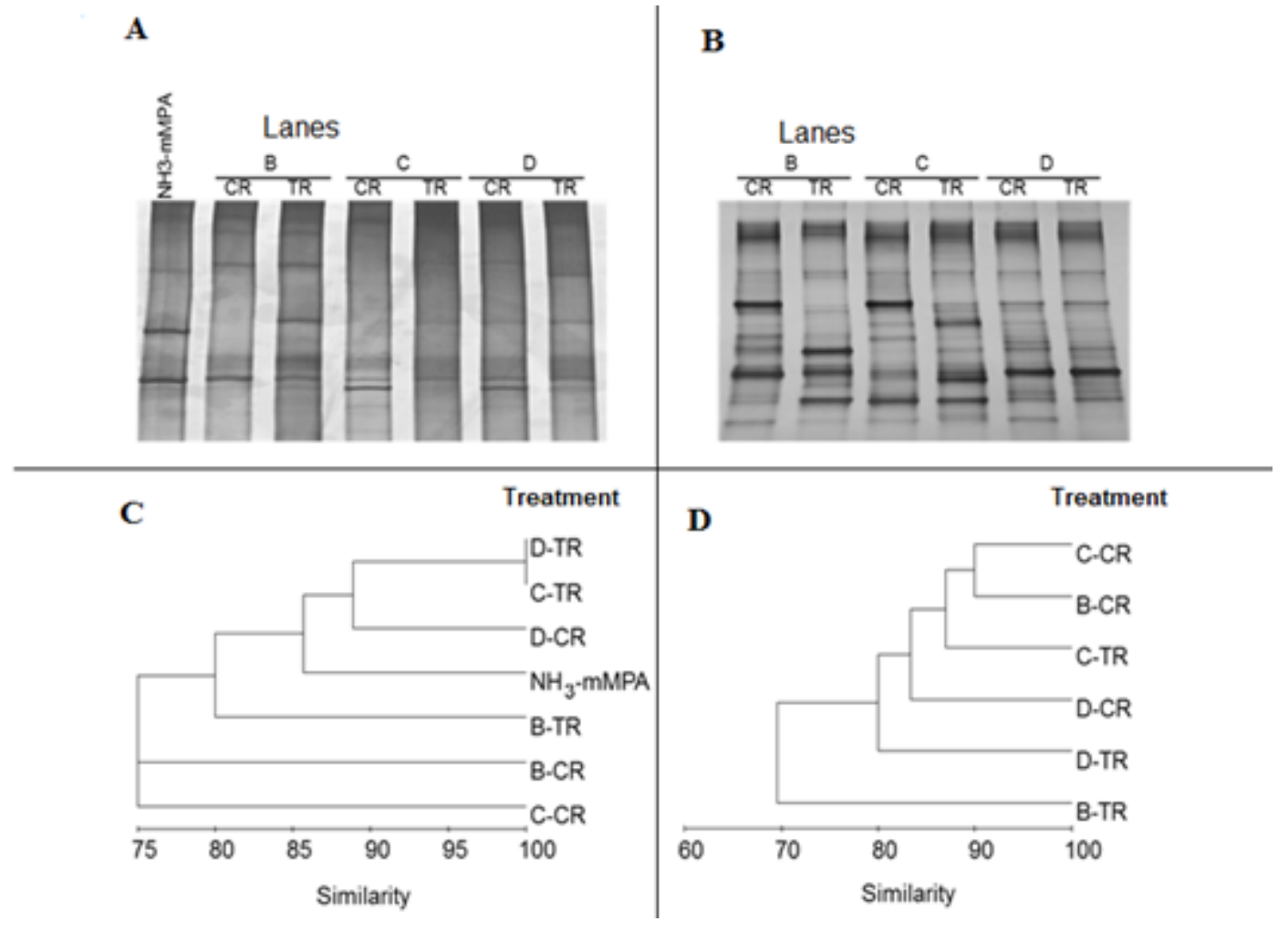

Figure 3

A. DGGE profiles of archaea. Gel bands recovered from 16S rDNA gels were sequenced and identified as EU544305 Methanomethylovorans sp., EU544306 and EU544307; two different species belonging to Methanosarcina sp. B. DGGE profiles of bacteria. C. Cluster analysis (WPGMA) using data from DGGE profiles of archaea in anaerobic biofilm to assess the similarity of taxonomic composition of consortia assigned to treatment of industrial waste rich in proteins, obtained from the control reactor (CR). D. Treatment Reactor (TR) lanes. B lanes- phase B, initial acclimatization at 37.7-128 mg NH3-N/L; C lanesphase $\mathrm{C}$, ammonia shock at $755 \mathrm{mg} \mathrm{NH3-N/L;} \mathrm{D} \mathrm{lanes-} \mathrm{phase} \mathrm{D,} \mathrm{final} \mathrm{reactor} \mathrm{recovery} \mathrm{from} 37.1$ to 41.2 mg NH3-N/L. 